\title{
TRACE ELEMENTS IN FINNISH SOILS AS RELATED TO SOIL TEXTURE AND ORGANIC MATTER CONTENT
}

\author{
Mikko SillanpäÄ \\ Department of Soil Science, Agricultural Research Centre, Helsinki
}

Received January 10, 1962

The total contents of trace elements in different soils vary far more than those of the major elements. Because of this the total contents in soils can be considered a better index of the availability of trace elements than of major elements, although not a sufficient assessment of it. In many respects, however, a knowledge of the total trace elements status of soils and of the factors affecting it is of great importance.

The trace element contents of mineral soils are primarily dependent on the parent rocks and minerals from which the soils have originated, as shown by several investigators $(3,12,16,17,22)$ but the relationship between the concentrations of a trace element in a soil and in its parent material is seldom close enough for satisfactory estimation of the former from the latter $(1,13)$. In Finland, owing to the heterogeneity of the parent rocks, to their occurrence in small areal exposures and to the ubiquitous glacial translocations and mixing of parent material, such a direct comparison is difficult.

Light-textured mineral soils have often been found to be lower in various trace elements than heavier soils $(2,5,6,7,8,14,23)$. This is also obvious from the results of VUORINEN (20), in which distinct differences can be seen between the amounts of trace elements in different Finnish soil types.

Organic soils have often been found to be low in total trace elements, while relatively high concentrations, of some trace elements may occur in mineral topsoils rich in organic matter $(4,8,17,22)$. The total contents of many trace elements are generally low in Finnish peat soils, and particularly in Sphagnum peats, (20, $21)$; most of the $\mathrm{Cu}$-deficiency cases, for example, are found in organic soils $(18,19)$. The same is also true in Sweden, particularly in the northern part of the country $(10,15)$.

The purpose of the study reported here was to establish the relation of the total contents of six trace elements to soil texture and organic matter content in Finnish soils covering a wide range of variation in respect of both soil factors in question.

\section{Materials and methods}

The effect of soil texture on the total contents of trace elements were studied in a series of 160 samples of mineral soils, on which particle size distribution analyses were made by the dry- and wet-sieving and pipette methods. For statistical analysis the particle size distribution was expressed as the mean weight diameter of particles (MWDP), calculated as follows: 


$$
\mathrm{MWDP}=\frac{\Sigma(\mathrm{n} \cdot \mathrm{d})}{\sum \mathrm{n}}
$$

where $\mathrm{n}=$ the percentage of a particle size fraction and $\mathrm{d}=$ the midpoint of the particle size class concerned (microns). The percentages of fractions coarser than $0.06 \mathrm{~mm}$, however, were combined with that of the finer finesand $(0.02-0.06 \mathrm{~mm})$ fraction. In considering the effect of soil texture, the effect of organic matter content varying from 0.1 to 15 per cent in these mineral soils was also taken into account in the statistical analyses.

In the study to determine the effect of organic matter, however, use was made of a considerably larger series of widely varying soil samples collected from different parts of Finland and analyzed in the laboratory of the Department of Soil Science during recent years. For statistical calculations the material (2637 samples) was classified according to the organic matter content.

The total amounts of trace elements were determined spectrographically, with silver and palladium as internal standards (9). The trace element contents were calculated on a volume basis and expressed as kilograms per hectare where the hectare corresponds to a hectare plow layer $20 \mathrm{~cm}$ in depth or a volume of 2 million liters. In a sample series including both organic and mineral soils, in which the bulk density of the latter may exceed that of the former by a factor of more than ten, the expression of the results on a weight basis can be misleading to the agriculturist, who is mainly interested in the elements in the soil horizons exploited by the common crop plants.

\section{Results and discussion}

For comparison of the effects of texture and organic matter content on the trace element contents of mineral soils, single and multiple regressions were calculated for both variables. The equations of the multiple regressions and correlation coefficients of both single regressions are given in Table 1. When comparing the regression and correlation coefficients it can be seen that the effect of texture on the total contents of cobalt, copper and nickel dominates completely. In the case of manganese the two factors are almost equally significant, while as regards the

Table 1. Multiple regressions of the total amounts of trace elements $(\mathrm{Y}, \mathrm{kg} / \mathrm{ha})$ on the mean weight diameter of particles $\left(\mathrm{X}_{1}, \mu\right)$ and organic matter content $\left(\mathrm{X}_{2}, \%\right)$ in mineral soils. $\mathrm{R}=$ coefficient of multiple correlation; $\mathrm{rx}_{1}$ and $\mathrm{rx}_{2}=$ correlation coefficients of single regressions of $\mathrm{Y}$ on $\mathrm{X}_{1}$ and $\mathrm{X}_{2}$ respectively. Significances at $5^{*}, 1^{* *}$ and $0.1^{* * *}$ per cent levels.

\begin{tabular}{llcll}
\hline $\begin{array}{c}\text { Trace } \\
\text { element }\end{array}$ & \multicolumn{1}{c}{ Multiple regression } & \multicolumn{1}{c}{$\mathrm{R}$} & \multicolumn{1}{c}{$\mathrm{rx}_{1}$} & \multicolumn{1}{c}{$\mathrm{rx}_{2}$} \\
\hline & & & & \\
$\mathrm{Co}$ & $\mathrm{Y}=57.4-12.9 \log \mathrm{X}_{1}-0.46 \log \mathrm{X}_{2}$ & $0.492^{* * *}$ & $-0.491^{* * *}$ & +0.132 \\
$\mathrm{Cu}$ & $\mathrm{Y}=\mathbf{9 1 . 0}-25.9 \log \mathrm{X}_{1}-1.39 \log \mathrm{X}_{2}$ & $0.510^{* * *}$ & $-0.509^{* * *}$ & +0.130 \\
$\mathrm{Mn}$ & $\mathrm{Y}=3545-764 \log \mathrm{X}_{1}+538 \log \mathrm{X}_{2}$ & $0.334^{* * *}$ & $-0.307^{* * *}$ & $+0.286^{* * *}$ \\
$\mathrm{Ni}$ & $\mathrm{Y}=130.7-35.0 \log \mathrm{X}_{1}-5.00 \log \mathrm{X}_{2}$ & $0.580^{* * *}$ & $-0.576^{* * *}$ & +0.107 \\
$\mathrm{~Pb}$ & $\mathrm{Y}=40.4+3.8 \log \mathrm{X}_{1}-4.03 \log \mathrm{X}_{2}$ & 0.125 & +0.105 & -0.097 \\
$\mathrm{Zn}$ & $\mathrm{Y}=141.6-14.5 \log \mathrm{X}_{1}+55.9 \log \mathrm{X}_{2}$ & $0.431^{* * *}$ & $-0.233^{* * *}$ & $+0.415^{* * *}$ \\
\hline
\end{tabular}




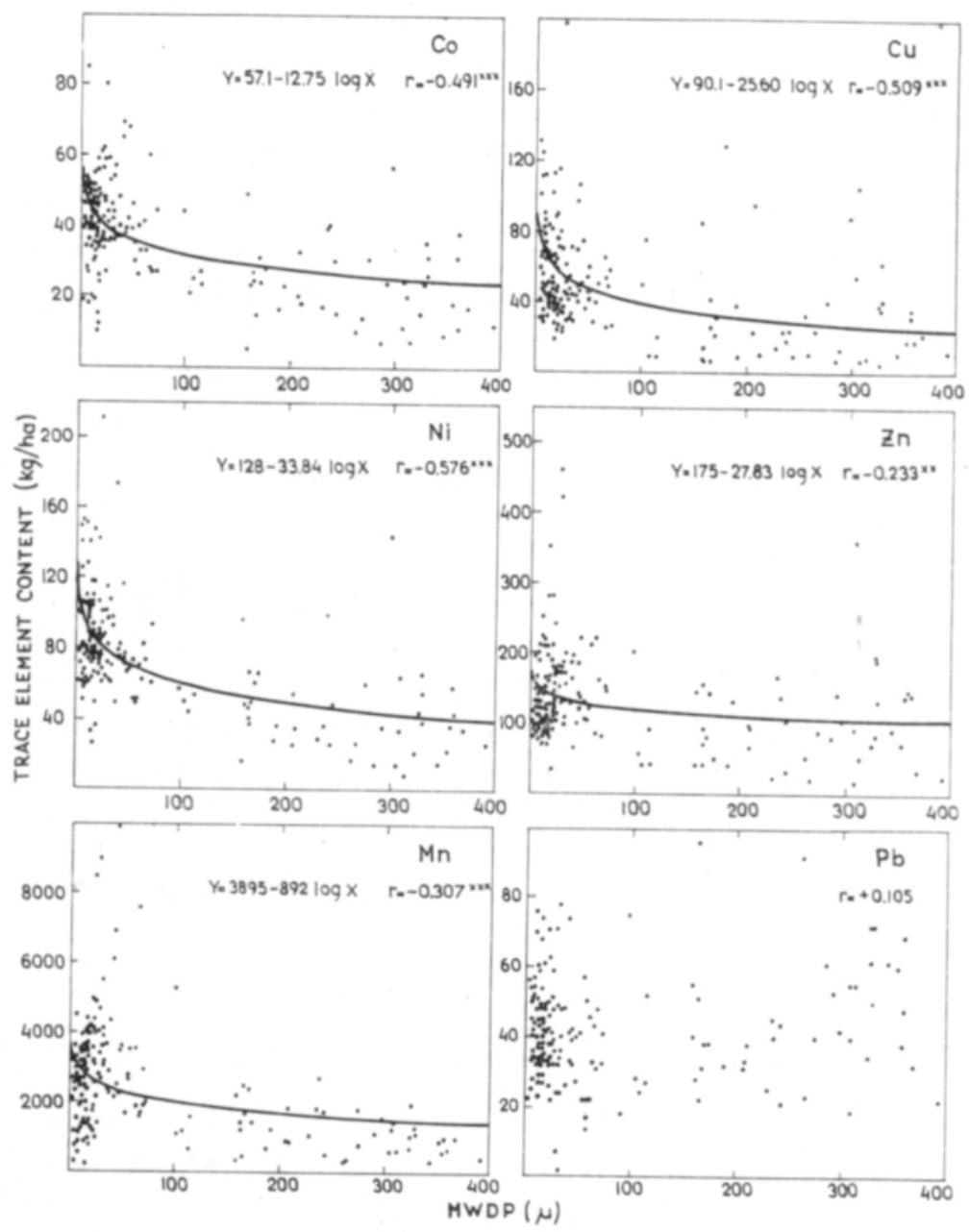

Fig. 1. Relations between the total contents of six trace elements and soil texture expressed as mean weight diameter of particles (MWDP); $\mathrm{r}=$ correlation coefficient.

total content of zinc the organic matter content of mineral soils seems to have more influence than their texture. The considerable effect of organic matter on the contents of the two last-mentioned elements can also be seen from Fig. 2. Neither the texture nor the organic matter content of soil seem to have any significant effect on the amounts of lead. When interpreting these results it should be noted that in these soils the variation range of the organic matter content is only from 0 to 15 per cent and the curvilinearity of the regression is apparently of higher degree, as will be shown later.

The single semilogarithmic regressions of the trace element contents on the mean weight diameter are given in Fig. 1. The regression equations for individual trace elements differ only slightly from the corresponding multiple regressions (Table 1), except in the case of zinc, where the effect of organic matter is more pronounced. 
In spite of wide variation there is a clear tendency for the trace element contents to decrease with increasing particle size. This relation seems to be curvilinear, as was indicated by the generally higher correlation coefficients for the semilogarithmic than for the linear regressions.

The tendency for the trace element contents to decrease with coarser soil texture is apparently connected with the geological origin of the soil material and with the rate of weathering, as pointed out by Mrtchell (12). Even though the soils in Finland are seldom derived from the parent rock in s it u, owing to the considerable glacial translocations and mixing that have taken place, the relative resistances to weathering of various rocks and minerals have undoubtedly influenced both the texture and consequently the trace element contents of the soils. Fine textured soils are likely to have been derived from more easily weathered rocks and minerals than coarse soils, in which resistant minerals like quartz are known to be the main constituents. Mitchell (11) presented a generalized scheme of the approximate order of stability of the commoner rock-forming minerals and the trace elements likely to be present in the minerals and soils containing such minerals. From this scheme in can be seen that most of those minerals containing the trace elements concerned in the present study are among the most easily weathered ones, while quartz is very resistant to weathering and likely to contain none of these elements. Lead forms an exception to this general rule and can seldom be expected to be present in the most easily weathered minerals. This may explain the lack of correlation between the amounts of lead and soil texture.

Correlations between the organic matter and trace element contents of soils were studied from a large sample material with a large variation in organic matter content: from almost plain mineral soils to peat soils containing only little mineral matter. The regression equations are given in Table 2 and regression lines in Fig. 2. The correlations of all regressions were highly significant $(r=>0.9)$. Since the regressions were calculated according to the mean values in classified sample material (organic matter basis), the correlation coefficients do not take into account the variation within the classes but the regressions show only the nature of the effect

Table 2. Regressions of total amounts of trace elements $(\mathrm{Y}, \mathrm{kg} / \mathrm{ha})$ on organic matter content $(\mathrm{X}, \%)$ in Finnish soils.

\begin{tabular}{llr}
\hline Cobalt & $\mathrm{Y}=21+46 \log \mathrm{X}-30(\log \mathrm{X})^{2}$ \\
Copper & $\mathrm{Y}=44+62 \log \mathrm{X}-42(\log \mathrm{X})^{2}$ \\
Manganese & $\mathrm{Y}=1171+2260 \log \mathrm{X}-1543(\log \mathrm{X})^{2}$ \\
Nickel & $\mathrm{Y}=35+99 \log \mathrm{X}-61(\log \mathrm{X})^{2}$ \\
Zinc & $\mathrm{Y}=23+196 \log \mathrm{X}-110(\log \mathrm{X})^{2}$ \\
\hline
\end{tabular}

of increasing organic matter without giving definite information about the variation. Because the correlations of the semilogarithmic regressions of second degree were considerably higher than those of first degree, the nature of the effect of - organic matter, as shown in Fig. 2, can be considered well established. 
In mineral soils the contents of the trace elements studied seem to increase with increasing organic matter and the maximum contents are likely to be found in soils containing from 5 to 15 per cent organic matter. Further increases of organic matter tend to decrease the total contents of trace elements until in organic soils they are at a minimum ( $\mathrm{kg} / \mathrm{ha}$ basis). This relation seems to be most pronounced for manganese and zinc, while for cobalt and copper the curvilinearity is somewhat less marked.

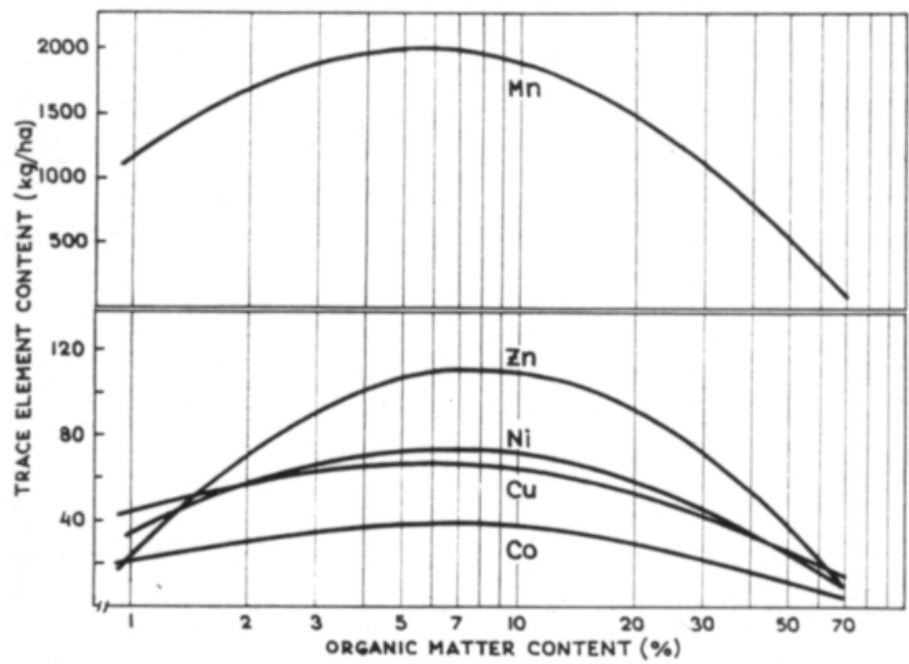

Fig. 2. Relations between the total amounts of trace elements and the organic matter content of Finnish soils. (For regression equations, see table 2).

Although the general trend of the relation is very similar for all five trace elements concerned, the basic reason of it seems not to lie in a similarity of their chemical behaviour but is presumably pedologic in nature: All trace elements have originated from the mineral matter of soils. Plants growing and decaying on a mineral soil derive trace elements from further below and accumulate them on the surface layer in addition to that already present in the mineral soil. This causes the trace elements to increase with the organic matter content of mineral soil. With further increases in the organic matter content, the proportion of the total trace elements made up by the elements in the mineral matter itself begins to decrease with a simultaneous decrease in the bulk density of the soil. Eventually, the contact between the peat layer on the top and mineral soil below becomes less and less close until finally in the top layer of a deep peat soil the only trace elements present are those gradually transported from the mineral subsoil by plants; the extreme cases of this development are the "raised swamps» of Sphagnum peat which are known to be very low in all nutrients. This general trend may be more apparent in the northern peats where, owing to climatic conditions, the decomposition of 
plant residues is slow, causing the fast accumulation of peat. Naturally, numerous local factors such as type of mineral subsoil, the drainage waters from surrounding areas, and leaching and fluctuation of the water table cause wide variations in this general tendency.

\section{$S u m m$ ary}

A study was conducted to evaluate the relation of the total contents of Co, $\mathrm{Cu}, \mathrm{Mn}, \mathrm{Ni}, \mathrm{Pb}$ and $\mathrm{Zn}$ on soil texture and organic matter content.

In spite of a wide variation, a clear tendency for the trace element contents ( $\mathrm{Pb}$ being an exception) to decrease with increasing particle size was found. The reason for this is believed to be associated with the geological origin of the soil material and with the relative resistance to weathering of the minerals from which the trace elements are derived.

In mineral soils the contents of trace elements increased with increasing organic matter and the maximum contents are likely to be found in soils containing from 5 to 15 per cent organic matter. A further increase in organic matter tends to decrease the total contents of trace elements expressed on a volume basis (kg/ha). The causes underlying this relation, which are believed to be pedological rather than chemical, are discussed.

\section{REFERENCES}

(1) Duarte, U. M. \& Leley, V. K. \& Narayana, N. 1961. Micronutrient status of the Bombay State soils. J. Indian Soc. Soil Sci. 9: 41-53.

(2) Gammon, N. Jr. \& Henderson, J. R. et al. 1953. Physical, spectrographic and chemical analyses of some virgin Florida soils. Fla. Agric. Exp. Sta. Bull. 524: 5-124.

(3) Graнam, E. R. 1953. Soil mineralogy as an index to the trace-element status of some Australian soils. Soil Sci. 75 : $333-343$.

(4) GYörI, D. 1958. Néhány talajtípus mikroelem készlete. Agrokém. Talajt. 7: 97-110.

(5) Hrll, A. C. \& Toth, S. J. \& BEAR, F. E. 1953. Cobalt status of New Jersey soils and forage plants and factors affecting the cobalt contents of plants. Soil Sci. 76: 273-284.

(6) Jensen, H. L. \& Lamm, C. G. 1961. On the zinc content of Danish soils. Acta Agric. Scand. 11: $63-80$.

(7) Johnson, F. R. \& Graham, E. R. 1952. Trace elements and Missouri soils. 1. Copper and cobalt contents of twenty-six soil types. Missouri Agric. Exp. Sta. Res. Bull. 517: 16 p.

(8) KeresztÉnY, B. \& NAGY, L. I. 1960. Nehány talaj szervesanyaghoz kötött molibden tartalmának vizsgálata. Agrokém. Talajt. 9: 495-500.

(9) LAPPI, L. \& MÄкıтıE, O. 1954. Quantitative spectrographic determination of minor elements in soil samples. Acta Agric. Scand. 5: 69-75.

(10) LundBlad, K. 1956. Koppar som växtnäringsämne. Växt-när.-nytt 12/4: 12 - 16.

(11) Mrtchels, R. L. 1955. Trace elements; Bear: Chemistry of the soil: 253-285: New York.

(12) - 1960. Trace elements in Scottish soils. Proc. Nutr. Soc. 19: 148-154. 
(13) Oertel, A. C. 1961. Relation between trace-element concentrations in soil and parent material. J. Soil Sci. 12: 119-128.

(14) Peive, J. \& Aizupiete, I. P. 1949. [Cobalt content in soils of the Latvian S.S.R.]. Latv. PSR Zināt. Akad. Vēstis. No 5: 19-28. (Ref. C.A. 47, 10165).

(15) Stenberg, M. \& Ekman, P. et al. 1949. Om kopparhalt i jord och vegetation och result av fleråriga gödslingsförsök i koppar. Medd. Kgl. Landbr. Akad. Vet. avd. 4: $106 \mathrm{~s}$.

(16) Swaby, R. J. \& PAssey, B. I. 1953. Availability of trace elements from rocks and minerals. Austr. J. Agric. Res. 4: $292-304$.

(17) Swarne, D. J. \& Mrtchell, R. L. 1960. Trace element distribution in soil profiles. J. Soil. Sci. 11: $347-368$.

(18) TAinio, A. 1953. Hivenaineiden puutteesta Suomen kasvinviljelyssä. Suomen Kemistilehti A 26: $193-196$.

(19) - - 1954. Hivenaineista ja niiden puutteesta erityisesti nurmiviljelyksillämme. Karjatalous 9: $221-226$.

(20) Vuorinen, J. 1958. On the amounts of minor elements in Finnish soils. J. Sci. Agric. Soc. Finland $30: 30-35$.

(21) - 1960. Hivenaineista Tampereen-Lempäälän seudun maaperässä. Maatal. ja koetoim. 14: $24-32$.

(22) Wells, N. 1960. Total elements in topsoils from igneous rocks: An extension of geochemistry. J. Soil Sci. 11: 409-424.

(23) Wright, J. R. \& Lawton, K. 1954. Cobalt investigations on some Nova Scotia soils. Soil Sci. 77: $95-105$.

S E L O T U S :

\title{
MAAN LAJITEKOOSTUMUKSEN JA ORGAANISEN AINEKSEN VAIKUTUKSESTA MAAN HIVENAINEIDEN PITOISUUKSIIN
}

\author{
Mikкo Sillanpää \\ Maantutkimuslaitos, Maatalouden tutkimuskeskus, Helsinki
}

Tutkimuksessa pyritään selvittämään maan koboltin, kuparin, mangaanin, nikkelin, lyijyn ja sinkin totaalimäärien riippuvuutta maan lajitekoostumuksesta ja orgaanisen aineksen määrästä.

Huolimatta suuresta hajonnasta koboltin, kuparin, mangaanin, nikkelin ja sinkin totaalimäärien ja maan lajitekoostumuksen välillä todettiin vallitsevan korrelaatiot, joiden mukaan hivenaineiden totaalimäärät pienenevät maan karkeusasteen kasvaessa (taulukko 1 ja kuva 1). Sen sijaan lyijyn totaalimääriin ei maan lajitekoostumuksella näytä olevan vaikutusta. Saatuihin tuloksiin vaikuttavat ilmeisesti sekä kivennäismaiden geologinen alkuperä että mineraalien rapautumisominaisuudet. Helposti rapautuvilla mineraaleilla on olennaisempi osuus hienojen kuin karkeiden kivennäismaiden mineraalikoostumuksessa; jälkimmäisissä taas rapautumiselle vähemmän alttiit mineraalit, varsinkin kvartsi, ovat vallitsevina. Tutkittavana olleista hivenaineista kobolttia, kuparia, mangaania, nikkeliä ja sinkkiä tavataan useimmissa helposti rapautuvissa mineraaleissa, lyijyä sen sijaan niissä on harvemmin. Rapautumista vastaan kestävämmät mineraalit, erityisesti kvartsi, ovat köyhiä hivenaineista. Tämä selittänee ainakin osittain sekä saadut korrelaatiot että sen puutteen lyijyllä.

Hivenaineiden totaalipitoisuudet, kiloina hehtaaria kohti ilmoitettuina, näyttävät kasvavan kivennäismaissa orgaanisen aineksen määrän kasvaessa tiettyyn rajaan asti, minkä jälkeen niiden määrät alkavat pienentyä ja todennäköinen minimi saavutetaan turvemaissa (taulukko 2 ja kuva 2 ). Regressioiden aluksi nouseva ja sitten laskeva suunta on ilmeisesti yhteydessä hivenaineiden rikastumiseen kivennäismaan pinnalle orgaanisen aineksen mukana, orgaanisen aineksen edelleen kasvavan pitoisuuden aiheuttamaan maan tilavuuspainon olennaiseen pienenemiseen ja turvemaissa varsinaisen hivenainelähteen, kivennäisaineksen, vaikutuksen vähenemiseen. 